\title{
ANALYSIS OF PROFIT SHARING SYSTEM BEEF CATTLE BREEDING BUSINESS IN KLAMBIR V KEBUN HAMPARAN PERAK SUBDISTRICT DELI SERDANG DISTRICT
}

\author{
Wilda Rifki, Y L Henuk, A H Daulay, Yunilas, N D Hanafi \\ Animal Production Program Study, Faculty of Agriculture, University of North \\ Sumatera, \\ Medan 20155, Indonesia \\ E-mail: wildarifki14@gmail.com
}

\begin{abstract}
Abstrak. The purpose of this research was to know the management of profit sharing system in the area, to analyze the income and profit of the investor and the farmer and the percentage of the contribution of the livestock business in fulfilling the income of the farmer family. This research was conducted in Klambir V Kebun Hamparan Perak Subdistrict Deli Serdang District for 2 month from July 2017 until August 2017. This research used primary data and secondary data. The location of the research and the determination of the respondents was determined purposively. Respondents consisted of 35 people who were divided into three scales: 16 respondents for 3-11 (small scale), 10 respondents for 12-20 (medium scale) and 9 respondents for scale > 20 (large scale) .

The results showed that the profit sharing system that is implemented in Klambir V Kebun is a profit sharing system for bulls with 50:50 share of the results. The income received by the investor and the farmer is different because in this business breeder farmers who spend for the maintenance of livestock while the investors only provide the livestocks germs. The bigger scale of business that the greater the income. The cattle breeding business with this profit sharing system has a value of $\mathrm{r} / \mathrm{c}$ ratio $>1$, which means the business is feasible to cultivate. The contribution of livestock at each successive scale is $53.40 \%, 60.22 \%$ and $67.79 \%$. Livestock can be categorized as a branch of business because it contributes $30-70 \%$ in fulfilling the household income.

Keywords: profit sharing, beef cattle, income, profit
\end{abstract}

\section{Introduction}

Beef cattle breeding business in Indonesia, especially in North Sumatra in general is still a community livestock business with the pattern of traditional maintenance. Beef cattle breeding business can grow if the livestock manager has capital. Capital is necessary both in the establishment and in the development of a business. This should be supported by good capital management. Good capital management includes efficient use of fixed costs and variable costs. These costs in the business of beef cattle are used for the procurement of production factors so that the utilization must be efficient so that the profit rate can be maximum Hoddi, et al.[1].

There is one cooperation that can help farmers to have initial capital in starting a livestock business. Cooperation is a profit-sharing system or commonly also called the system rowdy. The profit 
sharing system is the most widely used cooperative system by the people's farm. From the results of the initial survey that has been implemented, breeders in the Klambir V Kebun Hamparan Perak Subdistrict are doing a lot of livestock business with profit sharing system. Many farmers who want to make a livestock business but constrained by the lack of available capital, therefore the breeders look for ways to do the farm with a profit-sharing system. Based on the above, the researcher is interested to conduct research on the system of beef cattle production in Klambir V Kebun Hamparan Perak Subdistrict.

The purpose of this research is to know how the management of profit sharing system implemented in Klambir V Kebun, to analyze the level of income and profit obtained by breeder farmers from the profit sharing system implemented in Klambir V Kebun and to know the contribution of farm to the total income of rabid breeder households in Klambir V Kebun.

\section{Materials and Research Methods}

\subsection{Time and Place of Study}

The research was conducted in Klambir V Kebun, Hamparan Perak Subdistrict, Deli Serdang District. The study was conducted in July 2017 until August 2017.

\subsection{Method of Site Determination and Sampling Research}

The method used in determining the location and sampling is determined purposively (purposely), that is selected based on certain considerations in accordance with the purpose of the study. The sample used is breeder breeder who do business of beef cattle with profit sharing system at Klambir V Kebun Hamparan Perak Subdistrict.

\subsection{Method of collecting data}

The data collected in this study includes primary data and secondary data. Primary data were obtained from direct observation and direct interviews using the questionnaire provided. Secondary data is obtained from various scientific journals, text book, thesis (research report), as well as related institutions such as the Central Bureau of Statistics (BPS) and the office of Village Chief Klambir V Kebun.

\subsection{Data analysis method}

The method used in analyzing data in this research is qualitative and quantitative. Qualitative analysis describes the problems that exist in the field that is the management of profit sharing system in Klambir V Kebun Hamparan Perak Subdistrict, will be reviewed by linked with the attached library. Quantitative analysis is used to identify the income and profit of farmers as well as the percentage of livestock contribution to the total household income obtained by the mongers in Klambir V Kebun. To know the income and profit of breeder breeder seen by counting total cost of production, revenue, income and $\mathrm{r} / \mathrm{c}$ ratio. From these results then drawn the conclusion that is the answer to the problems raised in this research.

\section{Results and Discussion}

\subsection{Characteristics of Respondents}

Respondent in this research is breeder of beef cattle breeder with profit sharing system as many as 35 people in Klambir V Kebun Hamparan Perak Subdistrict. Characteristic description of respondents can be seen in Table 1. follows: 
Table 1. Characteristics of Respondents in Klambir V Kebun

\begin{tabular}{|c|c|c|c|}
\hline No. & Characteristics of Respondents & $\begin{array}{c}\text { Total } \\
\text { (people) }\end{array}$ & $\begin{array}{c}\text { Persentages } \\
(\%)\end{array}$ \\
\hline \multirow[t]{5}{*}{1.} & Age (years) & & \\
\hline & $25-35$ & 9 & 25,7 \\
\hline & $36-45$ & 13 & 37,1 \\
\hline & $46-55$ & 12 & 34,3 \\
\hline & $>55$ & 1 & 2,9 \\
\hline \multirow[t]{3}{*}{2.} & Gender & & \\
\hline & Male & 35 & 100 \\
\hline & Female & 0 & 0 \\
\hline \multirow[t]{6}{*}{3.} & Education & & \\
\hline & Not in school & 0 & 0 \\
\hline & Primary School & 11 & 31,4 \\
\hline & Junior High School & 14 & 40,0 \\
\hline & Senior High School & 10 & 28,6 \\
\hline & College & 0 & 0 \\
\hline \multirow[t]{5}{*}{4.} & Breeding Experience (years) & & \\
\hline & $3-9$ & 11 & 31,4 \\
\hline & $10-17$ & 13 & 37,1 \\
\hline & $18-25$ & 6 & 17,1 \\
\hline & $>25$ & 5 & 14,4 \\
\hline \multirow[t]{4}{*}{5.} & Number of Livestock (tails) & & \\
\hline & $3-11$ & 16 & 45,7 \\
\hline & $12-20$ & 10 & 28,6 \\
\hline & $>20$ & 9 & 25,7 \\
\hline \multirow[t]{7}{*}{6.} & Main Job & & \\
\hline & Breeders & 5 & 14,3 \\
\hline & Employees (BUMN/Swasta) & 7 & 20,0 \\
\hline & Entrepreneur & 9 & 25,7 \\
\hline & Construction workers & 7 & 20,0 \\
\hline & Workers & 5 & 14,3 \\
\hline & Etc. & 2 & 5,7 \\
\hline \multirow[t]{4}{*}{7.} & Incomes (Rp/months) & & \\
\hline & $\leq 1.000 .000$ & 2 & 5,7 \\
\hline & $1.100 .000-2.000 .000$ & 23 & 65,7 \\
\hline & $\geq 2.100 .000$ & 10 & 28,6 \\
\hline
\end{tabular}

Source: Primary Data Processed, 2017.

\subsection{Management of Profit Sharing System in Klambir V Kebun}

The system of beef cattle in Klambir V Kebun is done by an agreement between the owner of capital and breeder farmer. Agreements are usually only verbally by mutual agreement without any papers of power and so on. Owners of capital are usually from individuals, not from companies and many who are not from Klambir V Kebun. Generally farmers prefer a fattening system with 50:50 share, because it only takes a short time that is about 5 to 6 months of fattening then cattle sold and profits can be played back.

Capital given by the owner of capital is in the form of bulls with common type of cattle PO and local cattle. The amount given depends on the ability of the breeder breeder. Meanwhile, other facilities and infrastructure such as pens, equipment, feed, medicines are dependents for breeder breeders. The results obtained are usually in a single sale only at the time of Idul Adha (qurban), because the profit-sharing system used is the fattening system of bulls. In 1 fattening period usually has a time of \pm 6 months duration. If in the cattle there are livestock that died from disease then the breeders are not given a fine or sanction. But if the cattle die due to negligence of breeders like hit by a vehicle then the farmer must replace in accordance with the agreement with the owners of capital. The 
owner of the capital will get the result of a return of the vessel with an agreed value, then the profit is divided in two.

\subsection{Analysis of Incomes Breeders with Profit Sharing System}

The livestock breeders in this research are divided into 3 scale of ownership, that is the livestock with the number of livestock 3-11 (small scale) as many as 16 people, the litter with the number of livestock 12-20 (medium scale) as many as 10 people and the livestock with the number of cattle $>20$ (large scale) of 9 people, with 1 maintenance period for 6 months.

\subsubsection{Production cost}

Production costs are the total sum of fixed costs and variable costs incurred for each livestock raising. The following can be seen in Table 2. total production cost incurred:

Table 2. Total Production Cost for 1 Period of Beef Cattle Production Sharing System in Klambir V Kebun

\begin{tabular}{|c|c|c|c|c|}
\hline \multirow{2}{*}{ No. } & \multirow{2}{*}{ Description } & \multicolumn{3}{|c|}{ Breeders } \\
\hline & & $3-11$ & $12-20$ & $>20$ \\
\hline \multicolumn{5}{|c|}{ 1. $\quad$ Fixed Cost } \\
\hline & - $\quad$ Depreciation of Cage & 184.375 & 298.000 & 755.556 \\
\hline & - $\quad$ Depreciation of equipment & 52.972 & 131.475 & 148.105 \\
\hline \multicolumn{2}{|r|}{ Total Fixed Cost } & 237.347 & 429.475 & 903.660 \\
\hline \multirow[t]{8}{*}{2.} & Variable & & & \\
\hline & - $\quad$ Purchase of livestock & 53.468 .750 & 111.000 .000 & 234.277 .778 \\
\hline & - $\quad$ Salt/supplements & 208.500 & 451.200 & 973.333 \\
\hline & - $\quad$ Medicines & 299.125 & 611.200 & 1.293 .889 \\
\hline & - Workers & 5.400 .000 & 5.400 .000 & 5.400 .000 \\
\hline & Total Variable Cost & 59.376 .375 & 117.462 .400 & 241.945 .000 \\
\hline & Total Cost & 59.613 .722 & 117.891 .875 & 242.848 .660 \\
\hline & Total Cost/tail & 8.372 .346 & 7.991 .026 & 7.762 .587 \\
\hline
\end{tabular}

Source: Primary Data Processed, 2017.

\subsubsection{Fixed cost}

From Table 2. it can be seen that the components that exist at a fixed cost are the depreciation of cage and the depreciation of the equipment. Average fixed cost of ownership scale of 3-11 is Rp 237,347, -, ownership scale of 12-20 of fixed cost is Rp 429,475, - and on ownership scale> 20 of fixed cost is Rp 903,660, -.

\subsubsection{Variable Cost}

The cost of feed is not charged because the farmer can grass on the surrounding land of his own environment. To reimburse feed costs the labor cost is assumed to be the cost of feed.

To supplement the nutrients from the available feed, the breeder adds salt as a supplement or an additional feed to the livestock given by mixing it with cattle drinking water. In 2017, many farmers complain because the price of salt has increased dramatically twice as much. The normal salt price of $\mathrm{Rp} 1,500$ to $\mathrm{Rp} 2,000$ per kilogram increases to $\mathrm{Rp} 4000$ per kilogram. The need for salt is usually $1-2 \mathrm{~kg}$ per head per month.

Medicines in 1 regular period are given only once, ie at the time of the first going in the hence will be given worming medicine with wage Rp 40.000, - per head. Then the next treatment is usually there are some cattle infected with bloated diseases to be treated with a given drug with traditional ingredients such as boiled ginger and then drinking on sick livestock.

Workers costs are also not paid in cash because the workforce is the farmer itself. Workers cost is an assumption of the time that farmers spend in raising livestock and transportation costs incurred to take the feed. How to calculate labor cost is by calculating the amount of time (hours) spent to care for cows per day multiplied by the minimum regional wage (UMR) that applies per hour in Klambir V Kebun area. The hourly wage is assumed to be $\mathrm{Rp} \mathrm{7,500,} \mathrm{-} \mathrm{with} \mathrm{a} \mathrm{working} \mathrm{time} \mathrm{of} 4$ hours per day.

From the results of the data is processed in Table 2. the total production cost incurred for each number of livestock varies in each existing scale of ownership. At the ownership scale of 3-11 the total 
production cost is $\mathrm{Rp} 8,372,346$, -, the ownership scale of $12-20$ head of total production cost is $\mathrm{Rp}$ 7,991,021, - and on scale > 20 total production cost is Rp 7,762,587, - . The larger the scale of ownership the smaller the production cost incurred. This is due to the efficient use of existing workers.

\subsubsection{Revenue}

Revenue is the result obtained by the breeder after maintenance in 1 period (6 months). In this revenue-sharing system, revenue received only from the sale of livestock is done in 1 time during 1 period of maintenance, ie during Idul Adha (qurban). The amount of livestock selling price depends on the performance of livestock. Revenue results can be seen in Table 3. follows:

Table 3. Cattle Business Revenue for 1 Period of Beef Cattle Production Sharing System in Klambir V Kebun

\begin{tabular}{|c|c|c|}
\hline Scale & Sale of livestock (Rp) & Average (Rp) \\
\hline $3-11$ & 89.218 .750 & 12.330 .814 \\
\hline $12-20$ & 186.850 .000 & 12.604 .483 \\
\hline$>20$ & 395.277.778 & 12.610 .356 \\
\hline
\end{tabular}

Source: Primary Data Processed, 2017.

The amount of revenue earned depends on the size of the scale of ownership. The greater the scale of ownership the greater the acceptance of the can. At the ownership scale of 3-11 the received revenue is $\operatorname{Rp~} 89,218,750$ with the average selling price of $\mathrm{Rp} 12.330 .814$, - per head. On the scale of 12-20 received revenue is RP 186.850 .000 , - with average selling price Rp 12.604.483, - per head. While on a scale of $>20$ received is $\mathrm{Rp} 395,277,778$, - with the average selling price of $\mathrm{Rp}$ $12,610,356$, - per head. The selling price of livestock in Klambir V Kebun is Rp 11,000,000, - up to $\mathrm{Rp} 13,500,000,-$. The selling price of livestock depends on the weight of the livestock body and the condition of the livestock. The weight of livestock bodies in the village of Klambir V Kebun ranges from $180 \mathrm{~kg}$ to $280 \mathrm{~kg}$. The total revenue earned must be higher than the total production cost incurred for high profit.

\subsubsection{Income}

Income is divided into 2, namely the income of the capital owner and the income of the breeder. The amount of income of capital owners in the business of beef cattle in the village of Klambir V Kebun can be seen in Table 4. follows:

Table 4. Income of Beef Cattle Production Sharing System in Klambir V Kebun without Production Cost (Owner's Income)

\begin{tabular}{lccccc}
\hline Scale & $\begin{array}{c}\text { Sale of } \\
\text { Livestock (Rp) }\end{array}$ & $\begin{array}{c}\text { Price of } \\
\text { Livestock (Rp) }\end{array}$ & Income (Rp) & $\begin{array}{c}\text { Profit Sharing } \\
(\mathrm{Rp})\end{array}$ & $\begin{array}{c}\text { Income per tail } \\
(\mathrm{Rp})\end{array}$ \\
\hline $3-11$ & 89.218 .750 & 53.468 .750 & 35.750 .000 & 17.875 .000 & 2.482 .395 \\
$12-20$ & 186.850 .000 & 111.000 .000 & 75.850 .000 & 37.925 .000 & 2.545 .394 \\
$>20$ & 395.277 .778 & 234.277 .778 & 161.000 .000 & 80.500 .000 & 2.566 .354 \\
\hline
\end{tabular}

Source: Primary Data Processed, 2017.

The income of the owner of capital is the difference between the selling price of the livestock and the price of the fish that is issued because the owner of the capital does not pay for the facilities and infrastructure in the maintenance of beef cattle.

Furthermore, to know the income from breeder can be seen from Table 5. following:

Table 5. Income of Beef Cattle Production Sharing System in Klambir V Kebun with Production Cost (Net Revenue)

\begin{tabular}{|c|c|c|c|c|c|c|}
\hline \multirow[b]{2}{*}{ Scale } & \multirow[b]{2}{*}{$\begin{array}{l}\text { Livestock } \\
\text { Sale Value }\end{array}$} & \multicolumn{2}{|c|}{ Cost } & \multirow[b]{2}{*}{ Income } & \multirow[b]{2}{*}{ Profit Sharing } & \multirow{2}{*}{$\begin{array}{l}\text { Income per } \\
\text { tail }\end{array}$} \\
\hline & & Fixed Cost & $\begin{array}{c}\text { Variable } \\
\text { Cost }\end{array}$ & & & \\
\hline $3-11$ & 89.218 .750 & 237.347 & 59.376 .375 & 29.605 .028 & 14.802 .514 & 1.979 .234 \\
\hline $12-20$ & 186.850 .000 & 429.475 & 117.462 .400 & 68.958 .125 & 34.479 .063 & 2.306 .729 \\
\hline$>20$ & 395.277 .778 & 903.660 & 241.945 .000 & 152.429 .118 & 76.214 .559 & 2.423 .884 \\
\hline
\end{tabular}

Source: Primary Data Processed, 2017. 
If seen from Table 4. and Table 5. it can be seen that the profit gained from the owner of capital is greater than the breeder. This is the weakness of this system according to breeder farmers, but breeders also do not complain because they already feel helped to run this beef cattle business with the help of initial capital provided by the owners of capital and profits earned can be additional income.

\subsubsection{R/C Ratio (Return Cost Ratio)}

$\mathrm{R} / \mathrm{C}$ Ratio (Return Cost Ratio) livestock business will be profitable if the value of $\mathrm{r} / \mathrm{c}>1$. The greater the value of $\mathrm{rc}$ the greater the level of profits to be gained from the business. The following can be seen in Table $6 . \mathrm{r} / \mathrm{c}$ ratio value on beef cattle breeding business sharing system in Klambir $\mathrm{V}$ Kebun:

Table 6. Value of RC Ratio of Beef Cattle Farming Profit Sharing System in Klambir V Kebun

\begin{tabular}{|c|c|c|c|c|}
\hline Scale & Total Revenue & Total Cost & Profit & R/C Ratio \\
\hline $3-11$ & 89.218 .750 & 59.613 .722 & 29.605 .028 & 1,48 \\
\hline $12-20$ & 186.850 .000 & 117.891 .875 & 68.958 .125 & 1,58 \\
\hline$>20$ & 395.277 .778 & 242.848 .660 & 152.429 .118 & 1,62 \\
\hline
\end{tabular}

Source: Primary Data Processed, 2017.

The results seen in Table 6 . show the $\mathrm{r} / \mathrm{c}$ ratio of each of its ownership scales. The scale of 3 $11 \mathrm{r} / \mathrm{c}$ ratio value of 1.48 , on the scale of $12-20 \mathrm{r} / \mathrm{c}$ value obtained value of 1.58 and on scale $>20 \mathrm{r} / \mathrm{c}$ value obtained by 1.62 . The value of $\mathrm{r} / \mathrm{c}$ ratio obtained all the scale> 1 , meaning that the business can be said efficient because the value of benefits received in accordance with the costs incurred (profitable) both small, medium and large scale. This is in accordance with the statement of Soekartawi et al. [2], which states that a business is said to provide benefits when the value of $\mathrm{r} / \mathrm{c}$ ratio $>1$. The greater the value of $\mathrm{r} / \mathrm{c}$ ratio the more efficient the business and vice versa, the smaller the $\mathrm{r} / \mathrm{c}$ value, the less efficient business. This is also in accordance with the statement of Armunanto et al. [3], which states that efficiency in the actual business is also determined how each farmer's pattern of farmers in using all input factors. The use of input factors should promote efficient principles.

\subsection{Livestock Contribution to Household Rawing Breeder Income in Klambir V Kebun Hamparan Perak Subdistrict}

Table 7. Livestock Contribution to Household Income Breeders Raising Livestock Farming Cattle Production Sharing System in Klambir V Village

\begin{tabular}{lrrrcc}
\hline \multicolumn{1}{c}{ Scale } & $\begin{array}{c}\text { Income of } \\
\text { Livestock per } \\
\text { month }\end{array}$ & $\begin{array}{c}\text { Income of Main } \\
\text { Job per month }\end{array}$ & Total Income & $\begin{array}{c}\text { Contribution of } \\
\text { income of main } \\
\text { job (\%) }\end{array}$ & $\begin{array}{c}\text { Contribution } \\
\text { of Income of } \\
\text { Livestock (\%) }\end{array}$ \\
\hline 3-11 ekor & 2.467 .086 & 1.838 .304 & 4.017 .086 & 46,60 & 53,40 \\
12-20 ekor & 5.746 .511 & 3.534 .428 & 7.952 .264 & 39,78 & 60,22 \\
$>20$ ekor & 12.702 .427 & 5.463 .865 & 15.734 .210 & 32,21 & 67,79 \\
\hline
\end{tabular}

Source: Primary Data Processed, 2017.

From the data in Table 7. it can be seen that beef cattle farming accounts for more income than the main income of dairy farmers themselves. On the 3-11 scale livestock farms contributed $53.40 \%$ of the total main income, 12-20 livestock farms contributed $60.22 \%$ of the total revenue and scale > 20 livestock farms contributed $67.79 \%$ from total primary revenue. If livestock contributes income to total household income of $30 \%-70 \%$, then the livestock business can be said as a business branch. This is in accordance with the statement of Saragih [4], which states that livestock is a branch of business, where farmers seek mix farming with livestock as a business branch, with income from livestock of $30-70 \%$ (semi-commercial or integrated business). However, even if the income from livestock raises is greater than the income of the main job, the livestock breeder can not get the result every month because the income from the livestock business is only obtained within six months and usually within a year the farmer only does this business in one period. 


\section{Conclusions}

From the results and discussion there can be concluded that the business of beef cattle with the profit-sharing system in Klambir V Kebun is done with the fattening system of the bulls with a mutually agreed profit sharing agreement that is 50:50. The bigger the scale of the business the greater the benefits gained, vice versa. The income received by the investor and the farmer is different because in this business breeder farmers who spend for the maintenance of livestock while the investors only provide the livestocks germs. Beef cattle breeding business with this profit sharing system gives the advantage of getting the value of $\mathrm{r} / \mathrm{c}$ ratio $>1$, that is on 3-11 scale $\mathrm{r} / \mathrm{c}$ ratio is 1.48 , on the scale of 12-20 r / c ratio is 1.58 and on a scale $>20 \mathrm{r} / \mathrm{c}$ ration of 1.62. In the total household income of livestock breeder livestock farmers contribute income at each scale in sequence is $53.40 \%$, $60.22 \%$ and $67.79 \%$ which means that farms can be categorized as a branch of business because it contributes $30-70 \%$.

\section{References}

[1] Hoddi, A.H., M.B. Rombe dan Fahrul. 2011. Analisis Pendapatan Peternakan Sapi Potong di Kecamatan Tanete Rilau, Kabupaten Barru. Jurnal Agribisnis Vol. 3. Fakultas Peternakan. Universitas Hasanuddin Makassar. Makassar.

[2] Soekartawi, J., L. Dillon, J. B. Hardaker, dan A. Soeharjo. 1986. Ilmu Usaha Tani dan Penelitian Untuk Pengembangn Petani Kecil. UI-Press. Jakarta.

[3] Armunanto, Jum'atri Y., Cepriadi. 2014. Analisis Usaha Sapi Potong dengan Pola Kemitraan antara Investor (Pemodal) dengan Petani Peternak (Penggaduh) di Kelurahan Sail Kecamatan Tenayan Raya Kota Pekanbaru. Jurusan Agribisnis, Fakultas Pertanian, Universitas Riau. Pekanbaru.

[4] Saragih, B. 2000. Pengembangan Agribisnis Kecil. Departemen Ilmu-Ilmu Sosial Ekonomi. Institut Pertanian Bogor. Bogor. 